\title{
Article
}

\section{Systematic review with meta-analysis: the efficacy of tranexamic acid in upper gastrointestinal bleeding}

Twum-Barimah, Erica, Abdelgadir, Ibtihal, Gordon, Morris and Akobeng, Anthony K.

Available at http://clok.uclan.ac.uk/33274/

Twum-Barimah, Erica, Abdelgadir, Ibtihal, Gordon, Morris ORCID: 0000-00021216-5158 and Akobeng, Anthony K. (2020) Systematic review with metaanalysis: the efficacy of tranexamic acid in upper gastrointestinal bleeding. Alimentary Pharmacology \& Therapeutics, 51 (11). pp. 1004-1013. ISSN 02692813

It is advisable to refer to the publisher's version if you intend to cite from the work. http://dx.doi.org/10.1111/apt.15761

For more information about UCLan's research in this area go to http://www.uclan.ac.uk/researchgroups/ and search for <name of research Group>.

For information about Research generally at UCLan please go to http://www.uclan.ac.uk/research/

All outputs in CLoK are protected by Intellectual Property Rights law, including Copyright law. Copyright, IPR and Moral Rights for the works on this site are retained by the individual authors and/or other copyright owners. Terms and conditions for use of this material are defined in the policies page. 


\section{Tranexamic acid for upper gastrointestinal bleeding: a systematic review and meta-analysis of randomized controlled trials}

Erica Twum-Barimah MD, MPH, DTMH ${ }^{1}$, Ibtihal Abdelgadir $\mathrm{MD}^{2}$, Morris Gordon $\mathrm{PhD}^{3}$, Anthony K Akobeng MD, MPH ${ }^{2,4,5}$

${ }^{1}$ London School of Hygiene and Tropical Medicine, London, UK

${ }^{2}$ Department of Emergency Medicine, Sidra Medicine, Doha, Qatar

${ }^{3}$ University of Central Lancashire

${ }^{4}$ Division of Gastroenterology, Hepatology, and Nutrition, Sidra Medicine, Doha, Qatar

${ }^{5}$ Weill Cornell Medicine, Cornell University, Doha, Qatar

*Corresponding author: Prof. Anthony K Akobeng (akobeng@sidra.org)

Guarantor of the article: Anthony K Akobeng

Specific author contributions: AKA had the idea for the review. ETB and IA selected studies for inclusion and abstracted data. ETB wrote the first draft. IA, MG and AKA interpreted data and critically revised the paper for important intellectual content. All authors approved the final version.

Financial support: None

Potential competing interests: None declared.

Key words: tranexamic acid, upper gastrointestinal bleeding, meta-analysis, systematic review; anti-fibrinolytic 


\begin{abstract}
OBJECTIVES: The role of tranexamic acid in upper gastrointestinal bleeding is controversial. We have therefore performed a systematic review and meta-analysis of randomized controlled trials to assess the effect of tranexamic acid in patients with upper gastrointestinal bleeding.

METHODS: We searched PubMed, Embase, CINAHL, the Cochrane Central Register of Controlled Trials (CENTRAL), and relevant websites for randomised controlled trials investigating the effect of tranexamic acid published from inception to July 5, 2019. The primary outcome of interest was mortality. Estimates of effect were pooled with a randomeffects model. Quality of evidence was assessed using GRADE. This study is registered with PROSPERO (Registration number: CRD42018102516).
\end{abstract}

RESULTS: The search strategy identified 1547 citations. Eleven trials were eligible for inclusion. Of these, 10 trials comprising data for ???? patients compared tranexamic acid with placebo. There was a statistically significant effect of tranexamic acid in reducing mortality (RR $0.58,95 \%$ CI 0.42 to 0.82 ); there was no significant heterogeneity between the studies $\left(I^{2}=0 \%, \mathrm{P}=0.681\right)$. Pooled analysis of 6-7 studies that provided the relevant data showed no statistically significant difference between tranexamic acid and placebo with regard to the prevention of re-bleeding, surgical interventions, and the need for blood transfusions. The risk of adverse events with tranexamic acid was not different from placebo. The GRADE assessment rated the quality of the evidence in each outcome as ........

CONCLUSION: Tranexamic acid reduced risk of mortality compared with placebo. Tranexamic acid is a therapeutic option that could be offered to patients with upper gastrointestinal bleeding. 


\section{INTRODUCTION}

Upper gastrointestinal bleeding (UGIB) is defined as bleeding arising from any point in the gastrointestinal tract proximal to the suspensory ligament of the duodenum, the ligament of Treitz (1). It is a common emergency with mortality ranging from $14 \%$ in isolated bleeds and $33 \%$ following hospitalization with other comorbidities (2). Mortality increases with increasing age, co-existing comorbidities, as well as, with re-bleeding episodes (2,3). Despite great advances made in the management of patients presenting with UGIB, mortality rates remain high $(3,4)$. The main cause of death following UGIB is the resultant haemorrhagic shock (3).

UGIB can be grouped into non-variceal bleeds, which includes bleeds from peptic ulcers and gastritis, or variceal bleeds, which includes UGIB associated with cirrhosis or liver disease (2). It usually presents with hematemesis, which is the vomiting of blood or blood clots, or the passage of melena or dark, tarry stools resulting from alteration of blood in the gastrointestinal tract. Therapeutic upper GI endoscopy is the standard treatment for significant upper GI bleed (3). However, in instances where this intervention is not readily available, or in cases where patients refuse endoscopic therapy, alternate forms of treatment, such as, the use of medical therapy to achieve haemostasis becomes highly relevant, and even, life-saving.

Hyperfibrinolysis may contribute to some cases of UGIB (5). The possible beneficial effects of anti-fibrinolytic therapy for the treatment of UGIB has therefore been explored. The main anti-fibrinolytic therapies in clinical practice include tranexamic acid and aminocaproic acid (5). Tranexamic acid (TXA) is an anti-fibrinolytic agent which has gained widespread use in the last two decades in the reduction of bleeding in various trauma/surgical and obstetric haemorrhages. It has been shown to reduce the need for blood transfusion in many surgical patients $(6,7)$. It is a synthetic derivative of the amino acid lysine and its mechanism of action is through reversible blockade of lysine binding sites on plasminogen molecules, thereby inhibiting the interaction of plasminogen and the heavy chain of plasmin with lysine residues on the surface of fibrin $(6,8)$. It also directly inhibits plasmin non-competitively at high concentrations and thus, prevents the dissolution and degradation of fibrin clots by fibrin $(8,9)$.

However, the benefits of TXA in UGIB are controversial(3), and there is a need for further studies on this topic (10). A Cochrane systematic review published in 2014 found that tranexamic acid may have a beneficial effect on mortality but there were issues with the quality of the included trials (11). Following the publication of this systematic review, at least three new, randomized controlled trials have been published (12-14). In view of the recently published data, and the inconclusive nature of previous reports, we performed an up-to-date comprehensive systematic review and meta-analysis to evaluate the effect of TXA in upper gastrointestinal bleeding. 


\section{METHODS}

\section{Search Strategy and study selection}

This systematic review and meta-analysis is reported in accordance with the Preferred Reporting Items for Systematic Reviews and Meta-Analyses (The PRISMA statement) (15), and was registered at International Prospective Register of Systematic Reviews (PROSPERO; number CRD42018102516). We searched PubMed, Embase, CINAHL, and the Cochrane Central Register of Controlled Trials (CENTRAL) from inception to July 1, 2019. We also searched relevant websites (www.clinicaltrials.gov and www.controlled-trials.com) and reference lists of retrieved articles to try and identify additional citations that may have been missed through the electronic searches. Randomized controlled trials (RCT) that compared TXA use in UGIB to other treatment modalities for UGIB across all age groups were eligible for inclusion.

Studies were identified with the following search terms: (upper gastrointestinal OR synonyms) AND (bleeding OR synonyms) AND (tranexamic acid OR synonyms). We included both medical subject headings $(\mathrm{MeSH})$ and free text terms. There were no language restrictions. Two independent reviewers evaluated the titles and abstracts of papers to identify relevant studies. Articles identified were independently assessed by two reviewers using defined eligibility criteria. Disagreements between the reviewers were settled by consensus.

\section{Outcome Assessment}

The primary outcome was mortality. Secondary outcomes included duration of hospital stay, risk of rebleeding, the need for blood transfusion, the need for surgical interventions, and the occurrence of adverse events.

\section{Data extraction}

Data was extracted independently by two reviewers (ETB and IA) unto a Microsoft Excel spreadsheet using a pre-defined checklist. Extracted data included the following: risk of bias assessment, demographic information, methodology, intervention details, and reported outcomes. The extracted data were compared and the differences were discussed and resolved by consensus. If the authors were unable to reach a consensus, a third author (AKA) arbitrated. The data was entered into the Cochrane Collaboration's Review Manager (RevMan, version 5.3) for further processing and analysis.

\section{Assessment of risk of bias}

Two reviewers assessed the risk of bias in the selected studies in accordance with guidance published in the Cochrane handbook (16) Any disagreements were resolved by discussion and by inviting a third reviewer's input. Records of methods used to generate the randomization schedule and conceal the allocation of treatment, whether or not blinding was implemented for participants, personnel, and outcome assessment, whether there was evidence of selective reporting or incomplete outcome data were assessed.

\section{Data synthesis and statistical analysis}

Dichotomous outcome data were pooled and the impact of tranexamic acid, compared with placebo was expressed as a relative risk (RR) of mortality, re-bleeding, need for surgical 
intervention, need for blood transfusion with $95 \%$ confidence intervals (CI). Adverse events data were also summarised with RRs and 95\% CIs. All these analyses were decided a priori.

The statistical test of heterogeneity was utilised to quantify the diversity in the results of the different studies and to assess whether the variation between the trials in the meta-analysis were due to true heterogeneity or as a result of chance. Heterogeneity was assessed using the $\mathrm{I}^{2}$ statistic, with a cut-off of $\geq 50 \%$ and the chi-squared test with a $\mathrm{P}<0.10$ to define a significant degree of heterogeneity (17). Review Manager version 5.3 was used to generate the Forest plots of pooled RRs and 95\% CI for all the outcomes of interest.

For the primary outcome, mortality, the number needed to treat (NNT) for an additional beneficial outcome was calculated using the formula described in the Cochrane Handbook for Systematic Reviews of Interventions for computing number needed to treat from the results of a meta-analysis of risk ratios (18). This formula uses the pooled relative risk and an assumed control risk to compute the NNT. The calculation was further checked using an online calculator (Cates C. Visual Rx. Version 4, 2016. Available from http://www.nntonline.net. Accessed December 11, 2017).

\section{RESULTS}

The search strategy identified a total of 1540 citations, of which 63 met the criteria for fulltext review. A flow chart detailing the studies' selection process is shown in Figure 1. Following full text review, we included 11 trials comprising data for 2076 patients (1214,19-26). 3 new RCTs were identified since the last review (12-14). In 10 of the included studies, patients were randomised to TXA $(n=1071)$ or placebo $(n=942)$. In the eleventh study, patients were randomised to TXA or adrenaline. The age range of participants across the trials was 1 month old to 95 years.

Tranexamic acid was administered via various routes in these trials. Biggs, Barer, Engqvist administered it via both intravenous and oral routes $(21,23,25)$. It was administered solely intravenously by Von Holstein (24), and orally by Cormack (20) and Bergqvist (22). In Saidi 2017, the tranexamic acid was administered via nasogastric tube (12), and either intravenously or via nasogastric tube topically by Bagnenko and Tavakoli $(13,19)$.

The risk of bias assessment in the trials is summarised in the "Risk of bias summary" (Figure $2,3)$. We rated 5 trials as having adequate randomisation and allocation concealment $(12,13,23,25,26)$. In 6 of the trials, participants were adequately blinded to the intervention and to outcome assessors $(12,13,21,23,24,26)$. No trial was rated as having a high risk of bias for incomplete outcome data due to attrition. All but 1 trial were rated as low risk of bias for selective reporting (23), and no trial reported to be funded by industry.

Based on GRADE, the overall quality of evidence was rated as ???? low or moderate for the main outcomes (appendix).

\section{Efficacy of Tranexamic acid for preventing deaths in UGIB}

Ten RCTs involving 2013 patients compared TXA with placebo in the treatment of UGIB $(12,13,19-26)$. In a pooled analysis of all 10 trials, TXA significantly reduced risk of death (Figure 4). 53 of 1071 (4.9\%) of patients who received TXA died compared to 9.4\% (89/942) 
of patients who received placebo (RR $0.59,95 \%$ CI $0.43-0.82, I^{2}=0 \%, p=0.81$ ). Sensitivity analysis conducted using a fixed effects model did not change the results (Figure 5).

The NNT for this outcome was calculated using the maximum and minimum control risk of death amongst the included trials. In a population whose baseline risk of death (i.e. risk of death with placebo) was similar to the trial reported by XXX, (Ref) the NNT would be XX (95\% CI X-Y). In another population whose baseline risk was similar to the trial by XX,(Ref) the NNT would be XX (95\% CI X-Y).

In the one study that was not included in the meta-analysis, there were no mortalities recorded in the TXA or placebo groups(14).

\section{Efficacy of Tranexamic acid for preventing re-bleeding in UGIB}

Eight of the trials included in the meta-analysis compared the number of re-bleeding events in the Tranexamic acid and Placebo groups $(12,13,19,20,23-26)$.

In total, there were $141(15 \%)$ re-bleeding events in the 940 patients that received tranexamic acid, compared to $159(7.3 \%)$ re-bleeding events in 810 patients allocated to receive placebo (RR of re-bleeding $=0.79 ; 95 \% \mathrm{CI}=0.61-1.02$; Figure 6 ). The was some heterogeneity between the studies, $\mathrm{I}^{2}=23 \%, \mathrm{P}=0.24$.

\section{Efficacy of Tranexamic acid for preventing surgical interventions in UGIB}

Nine trials compared the need for surgical interventions in the tranexamic acid and placebo groups $(12,13,19,21-26)$. There were 93 (9.3\%) surgical interventions in the 995 patients that received tranexamic acid, compared to $116(13.4 \%)$ surgical interventions in the 868 patients allocated to receive placebo ( $\mathrm{RR}$ of re-bleeding $=0.70 ; 95 \% \mathrm{CI}=0.43-1.13$; Figure 7 ). The heterogeneity between the studies, $\mathrm{I}^{2}=60 \% ; \mathrm{P}=0.01$.

\section{Efficacy of Tranexamic acid for preventing need for blood transfusion in UGIB}

A total of eight trials compared the frequency of blood transfusions between the tranexamic acid and placebo groups (13,20-26). Out of the 951 patients that received tranexamic acid, there were $385(40.5 \%)$ blood transfusions, compared to $388(47.8 \%)$ blood transfusions out of 812 patients allocated to receive placebo ( $\mathrm{RR}$ of mortality $=1.00 ; 95 \% \mathrm{CI}=0.93-1.08$; Figure 8). There was no heterogeneity between studies ( $\mathrm{I} 2=0 \%, \mathrm{P}=0.46$ )

\section{Efficacy of Tranexamic acid vs Placebo in preventing Thromboembolic events in UGIB}

Six trials assessed the development of thromboembolic events in both groups $(12,13,19,20,24,25)$. There were $8(1.4 \%)$ thromboembolic events in the 584 patients that received tranexamic acid, compared to $8(1.8 \%)$ thromboembolic events out of 457 patients allocated to receive placebo ( $\mathrm{RR}$ of mortality $=0.89 ; 95 \% \mathrm{CI}=0.17-4.59$; Figure 9$)$. The heterogeneity, $\mathrm{I}^{2}$, between studies was $55 \%, \mathrm{P}=0.11$.

\section{Development of thrombophlebitis in Tranexamic acid vs Placebo in UGIB}

Two trials compared the development of thrombophlebitis in both groups $(21,24) .5(3 \%)$ out of a total of 175 patients that received tranexamic acid developed thrombophlebitis, compared to $2(1 \%)$ out of 179 patients allocated to receive placebo $(\mathrm{RR}=2.02 ; 95 \% \mathrm{CI}=$ 0.44-9.26; Figure 10). There was no heterogeneity between studies, $\mathrm{I}^{2}=0 \%, \mathrm{P}=0.43$ ) 


\section{DISCUSSION}

Current UK and American guidelines on the treatment of UGIB do not recommend the use of tranexamic acid $(27,28)$. This is because at the time of the publication of these guidelines, there were no conclusive evidence on the benefits of tranexamic acid in UGIB. A Cochrane meta-analysis published in 2014 found that tranexamic acid may have a beneficial effect on mortality (11), but there were issues with the quality of the included trials. Moreover, other outcomes such as rebleeding were not reduced. Following the publication of this metaanalysis, 3 RCTs have been published on the topic (12-14). In light of these recently published data, we conducted an up-to-date systematic review and meta-analysis to evaluate the effect of TXA versus placebo or other interventions in patients with UGIB. By including data from the recent trials, the overall sample size is increased thereby improving the statistical power of our meta-analysis.

The results of our meta-analysis show that TXA reduces the risk of death compared to placebo in patients with upper gastrointestinal bleeding. There was however no significant reduction in the risk of rebleeding or need for surgery. There was also no difference between the two groups with regard to risk of adverse events such as thromboembolic events. These results are consistent with the findings of the two most recent trials $(12,13)$ and with the results of recent observational studies (TTT) that reported that TXA was associated with a lower risk of death. Results from a large trial which began in 2013, the 'Haemorrhage alleviation with tranexamic acid- Intestinal system' (HALT-IT) are still pending (29).

Whilst the results of our analysis show that TXA is superior to placebo in patients with $\mathrm{UGIB}$, the absolute benefit is modest with a number needed to treat ranging from $\mathrm{X}$ to $\mathrm{Y}$ patients to prevent one additional death. This may raise issues about the cost-effectiveness of TXA. The NNT was calculated for two different baseline risks, the maximum and minimum control risk in the included trials (REF). Whilst the NNT is a clinically useful way to present results (REF), the limitations of a NNT calculated from pooled data must be considered. We will suggest that readers apply the relative risk estimates from our meta-analysis to baseline risk data from their own populations to allow a more representative NNT to be calculated for their patients.

In summary, this updated systematic review and meta-analysis has demonstrated that TXA can be effective in improving patient outcome by reducing mortality in UGIB. 
FIGURE 1 Flow diagram of the study selection process

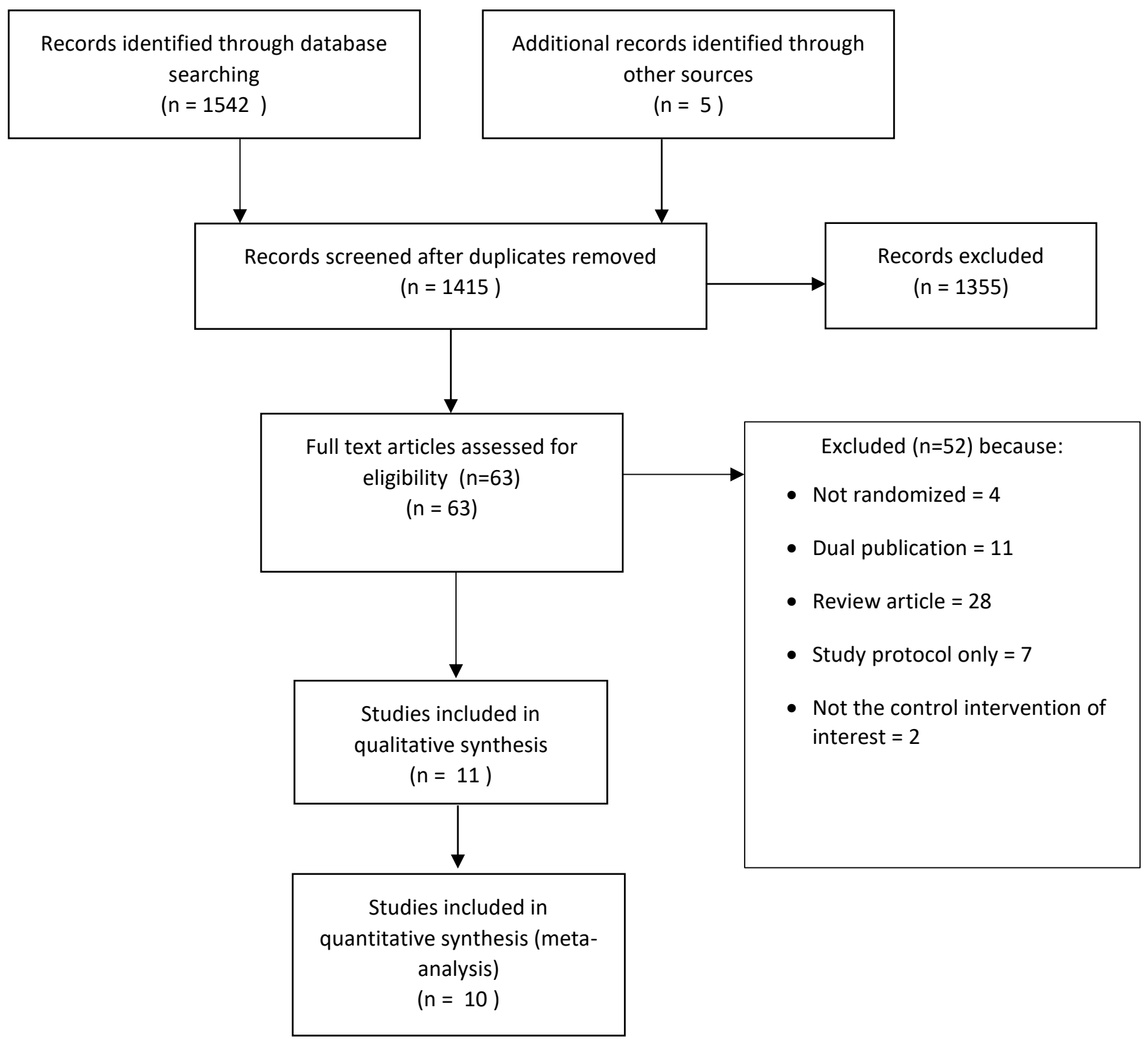


FIGURE 2 Summary of risk of bias of included studies: author's judgement about each risk of bias item for each included study

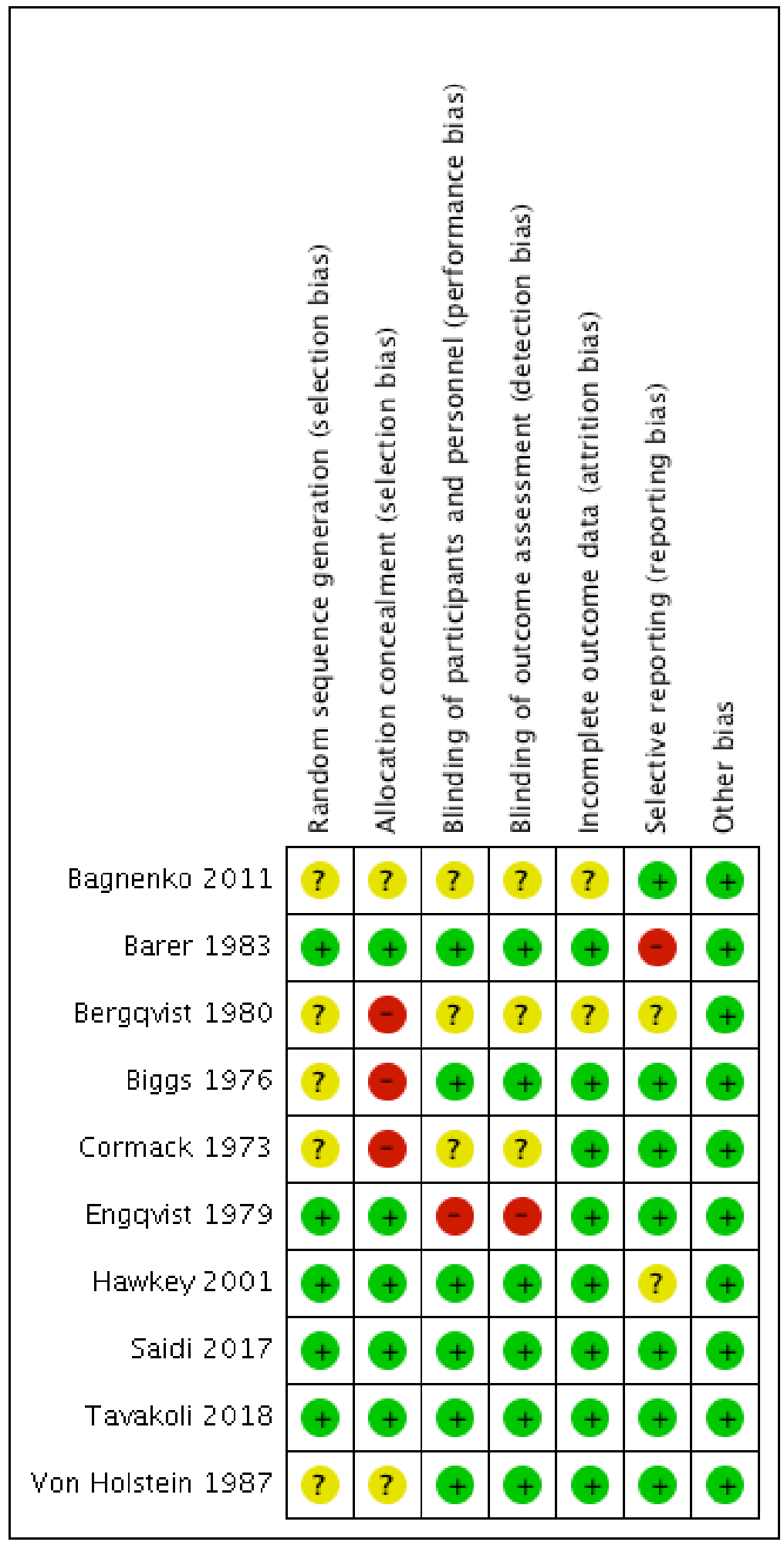

FIGURE 3. Summary of risk of bias of included studies: Graph review of author's judgement about each bias item expressed as percentages across all included studies 


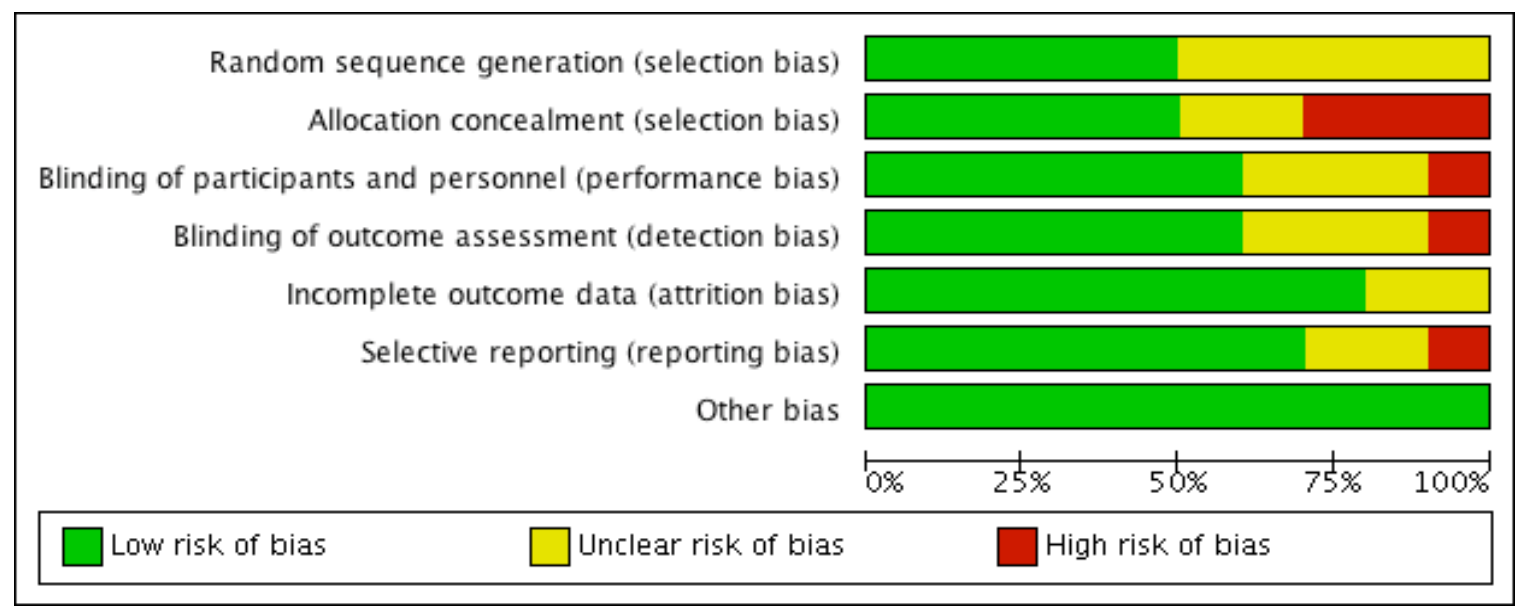


TABLE 1 Characteristics of Randomized Controlled Trials of Tranexamic Acid versus Placebo in UGIB

\begin{tabular}{|c|c|c|c|c|c|}
\hline Study, Country and Setting & Criteria used to define UGIB & Sample Size and Characteristics & Tranexamic Acid Dose Used and duration of Therapy & Control Used and Duration of Therapy & Methodology \\
\hline $\begin{array}{l}\text { Cormack 1973, UK, } \\
\text { Gloucestershire Royal } \\
\text { Hospital }\end{array}$ & Presence of frank hematemesis & $\begin{array}{l}150 \text { participants of all ages } \\
\text { grouped into age groups }<45,45- \\
60,>60 \text { years. } 49 \text { males and } 27 \\
\text { females in TXA group and } 51 \\
\text { males and } 23 \text { females in Control } \\
\text { group }\end{array}$ & Tranexamic acid $1.5 \mathrm{~g} 8$ hourly for 7 days. & Placebo tablets 8 hourly for 7 days & $\begin{array}{l}\text { Double-blind RCT. Methods } \\
\text { of randomization and } \\
\text { concealment of allocation } \\
\text { not stated. No concomitant } \\
\text { medications given. }\end{array}$ \\
\hline $\begin{array}{l}\text { Biggs JC et al 1976, Australia, } \\
\text { St Vincent Hospital }\end{array}$ & $\begin{array}{l}\text { Patients presenting with } \\
\text { haemorrhage (observed by medical } \\
\text { officer) and requiring admission. } \\
\text { Finding bleeding sites using } \\
\text { endoscopy, barium studies, } \\
\text { operations, and necroscopy }\end{array}$ & $\begin{array}{l}200 \text { participants of unspecified } \\
\text { ages. } 73 \% \text { males in the } \\
\text { intervention group and } 83 \% \\
\text { females in Control group }\end{array}$ & $\begin{array}{l}\text { Ig IV and } 1 \mathrm{~g} \text { oral Tranexamic acid administered } 8 \\
\text { hourly for } 48 \text { hours, followed by } 1 \mathrm{~g} \text { oral Tranexamic acid } \\
\text { 8hourly for } 72 \text { hours }\end{array}$ & $\begin{array}{l}\text { 1g IV and } 1 \mathrm{~g} \text { oral Placebo administered } 8 \\
\text { hourly for } 48 \text { hours, followed by } 1 \mathrm{~g} \text { oral } \\
\text { PLacebo } 8 \text { hourly for } 72 \text { hours }\end{array}$ & $\begin{array}{l}\text { Double-blind RCT. Method } \\
\text { of randomization and } \\
\text { concealment of allocation } \\
\text { not stated. No concomitant } \\
\text { medications given }\end{array}$ \\
\hline $\begin{array}{l}\text { Bergqvist D 1980, Sweden, } \\
\text { ICU }\end{array}$ & $\begin{array}{l}\text { Patients with massive bleeding- } \\
\text { hematemesis and /or melena with } \\
\text { circulatory involvement }\end{array}$ & $\begin{array}{l}50 \text { participants with mean age } \\
\text { range of } 60.8(23-82) \text { years in } \\
\text { Tranxamic acid group and } 57.6 \text { (26- } \\
85 \text { ) years in the control group. A } \\
\text { total of } 14 \text { males and } 7 \text { females in } \\
\text { the Tranexamic acid group and } 20 \\
\text { males and } 2 \text { females in the control } \\
\text { gorup }\end{array}$ & $\begin{array}{l}\text { Oral solution of } 2 \mathrm{~g} \text { Tranexamic acid administered via } \\
\text { gastric tube every } 4 \text { hours within } 1 \text { hour of arriving at } \\
\text { the ICU }\end{array}$ & $\begin{array}{l}\text { Oral solution of Placebo administered via } \\
\text { gastric tube every } 4 \text { hours within } 1 \text { hour } \\
\text { of arriving at the ICU }\end{array}$ & $\begin{array}{l}\text { Double-blind RCT. Method } \\
\text { of randomization and } \\
\text { concealment of allocation } \\
\text { stated. Method of } \\
\text { concealment not stated. } \\
\text { Dextran given when needed. }\end{array}$ \\
\hline $\begin{array}{l}\text { Barer D et al 1983, UK, } \\
\text { Medical wards of the } \\
\text { Nottingham City and } \\
\text { University hospitals }\end{array}$ & Criteria not stated & $\begin{array}{l}775 \text { patients with hematemesis or } \\
\text { melena or both. No age limits. }\end{array}$ & $\begin{array}{l}1 \mathrm{~g} \text { of IV Tranexamic acid administered } 6 \text { hourly for } 48 \\
\text { hours, then orally every } 6 \text { hours for } 5 \text { days }\end{array}$ & $\begin{array}{l}400 \mathrm{mg} \text { of IV Ciimetidine or Placebo } \\
\text { tablets administered } 6 \text { hourly for } \\
48 \text { hours, then orally every } 6 \text { hours for } 5 \\
\text { days }\end{array}$ & $\begin{array}{l}\text { Double-blind RCT. Method } \\
\text { of randomization and } \\
\text { concealment of allocation } \\
\text { stated. Concomitant } \\
\text { medications with the } \\
\text { exception of H2 antagonists } \\
\text { given when needed }\end{array}$ \\
\hline $\begin{array}{l}\text { Von Holsein et al 1987, } \\
\text { Sweden, Department of } \\
\text { Surgery - University of Lund } \\
\text { and Central Hospital in } \\
\text { Helsingborg }\end{array}$ & $\begin{array}{l}\text { Presence of demonstrable benign } \\
\text { gastric or duodenal lesion via } \\
\text { endoscopy as the bleeding source }\end{array}$ & $\begin{array}{l}154 \text { patients. } 18-879 \text { mean } 62.4 \text { ) in } \\
\text { TXA group and 32-95 (mean 65.4) } \\
\text { in control group. Male-to-female } \\
\text { ratios in Tranexamic acid group is } \\
50: 22 \text { and in the control group } \\
58: 24\end{array}$ & $\begin{array}{l}\text { 1g of IV Tranexamic acid administered } 4 \text { hourly for } 3 \\
\text { days within } 2 \text { hours of admission }\end{array}$ & $\begin{array}{l}\text { 1g of Placebo administered } 4 \text { hourly for } 3 \\
\text { days within } 2 \text { hours of admission }\end{array}$ & $\begin{array}{l}\text { Prospective Double-blind } \\
\text { RCT. Method of } \\
\text { randomisation and } \\
\text { concealment of allocation } \\
\text { stated. All patients received } \\
\text { usual conservative } \\
\text { medication. }\end{array}$ \\
\hline $\begin{array}{l}\text { Saidi H et al 2017, Iran, Hazrat } \\
\text { Rasool General Hospital }\end{array}$ & $\begin{array}{l}\text { Presence of endoscopically confirmed } \\
\text { benign gastric or duodenal lesions in } \\
\text { patients presenting with clinical signs } \\
\text { of UGIB }\end{array}$ & $\begin{array}{l}131 \text { patients of which } 82 \text { were } \\
\text { males and } 49 \text { were females }\end{array}$ & $\begin{array}{l}\text { 1g Tranexamic acid diluted in } 250 \mathrm{cc} \text { of saline solution } \\
\text { administered via nasogastric tube }\end{array}$ & $\begin{array}{l}\text { Placebo (physiologic saline) } \\
\text { administered via nasogastric tube }\end{array}$ & $\begin{array}{l}\text { Double-blind RCT. Method } \\
\text { of randomisation stated. } \\
\text { Method of concealment of } \\
\text { allocation not stated. All } \\
\text { patients received } \\
\text { concomitant therapy }\end{array}$ \\
\hline $\begin{array}{l}\text { Tavacoli et al 2018, Iran, } \\
\text { Rasoul-e-Akram Hospital in } \\
\text { Tehran }\end{array}$ & $\begin{array}{l}\text { History of hematochezia, melena and } \\
\text { hematemesis. Also physical } \\
\text { examination and/or lab test findings }\end{array}$ & $\begin{array}{l}410 \text { patients older than } 18 \text { years. } \\
274 \text { males and } 136 \text { females }\end{array}$ & $\begin{array}{l}\text { 1g Tranexamic acid administered } 6 \text { hourly intravenously } \\
\text { or topically via nasogastric tube and systemic } \\
\text { Tranexamic acid for } 24 \text { hours }\end{array}$ & $\begin{array}{l}\text { Placebo (Sodium Chloride } 0.9 \% \text { ) } \\
\text { administered for } 24 \text { hours }\end{array}$ & $\begin{array}{l}\text { Double-blind RCT. Method } \\
\text { of randomization and } \\
\text { concealment of allocation } \\
\text { stated. All patients received } \\
\text { conventional medical } \\
\text { therapy }\end{array}$ \\
\hline $\begin{array}{l}\text { Engqvist A 1979, Sweden, } \\
\text { Sødersjukhuset }\end{array}$ & $\begin{array}{l}\text { All patients treated for massive upper } \\
\text { gastrointestinal haemorrhage (history } \\
\text { of hematemesis and/or melena and } \\
\text { with signs of circualtory } \\
\text { embarassment) in the intensive care } \\
\text { unit }\end{array}$ & $\begin{array}{l}149 \text { patients included. } 55 \text { males } \\
\text { and } 21 \text { females in the Tranexamic } \\
\text { acid group and } 61 \text { males and } 12 \\
\text { females in the Placebo group }\end{array}$ & $\begin{array}{l}\text { 1g IV Tranexamic acid for } 3 \text { days followed by } 1.5 \text { g orally } \\
4 \text { times daily for } 4 \text { days }\end{array}$ & $\begin{array}{l}\text { IV Placebo for } 3 \text { days followed by } 1.5 \mathrm{~g} \\
\text { orally } 4 \text { times daily for } 4 \text { days }\end{array}$ & $\begin{array}{l}\text { Double-blind RCT. Method } \\
\text { of randomization and } \\
\text { concealment of allocation } \\
\text { stated. No concomitant } \\
\text { medications given. }\end{array}$ \\
\hline $\begin{array}{l}\text { Rafeey M et al 2016, Iran, } \\
\text { Children's Hospital-Tabriz }\end{array}$ & $\begin{array}{l}\text { Presence of endoscopically confirmed } \\
\text { gastric or duodenal bleeding }\end{array}$ & $\begin{array}{l}63 \text { children between ages of } 1 \\
\text { month to } 15 \text { years old. } 30 \text { girls and } \\
33 \text { boys were included in the study }\end{array}$ & $\begin{array}{l}10 \mathrm{ml} \text { of saline with } 5 \mathrm{ml} \text { of Tranexamic acid }(500 \mathrm{mg} \\
\text { Tranexamic acid per vial) administered directly under } \\
\text { endoscopic therapy by injecting into the submucosa of } \\
\text { peptic ulver margins }\end{array}$ & $\begin{array}{l}10 \mathrm{ml} \text { of saline with } 5 \mathrm{ml} \text { of Epinephrine } \\
(1 / 10,000) \text { administered directly under } \\
\text { endoscopic therapy by injecting into the } \\
\text { submucosa of peptic ulcer margins }\end{array}$ & $\begin{array}{l}\text { Methods of randomisation } \\
\text { and concealment of } \\
\text { allocation not stated. All } \\
\text { patients received supportive } \\
\text { medication of IV fluids and } \\
\text { proton pump inhibitor drugs }\end{array}$ \\
\hline $\begin{array}{l}\text { Hawkey et al 2001, UK, } 2 \\
\text { hospitals in Nottingham }\end{array}$ & Upper GI endoscopy of patients & $\begin{array}{l}414 \text { male and female patients } \\
\text { randomized of which } 316 \text { were } \\
\text { endoscopically confirmed UGIB. } \\
\text { Mean age of patients was } 58.4 \\
(19.9 \%) \text {. }\end{array}$ & $\begin{array}{l}\text { Tranexamic acid } 2 \mathrm{~g} \text { stat, followed by } 1 \mathrm{~g} \text { four times daily } \\
\text { alone or administered with Lansoprazole } 60 \mathrm{mg} \text { stat, } \\
\text { then } 30 \mathrm{mg} \text { four times daily }\end{array}$ & Placebo given four times dailly & $\begin{array}{l}\text { Double-blind RCT, double } \\
\text { dummy. Method of } \\
\text { randomization stated. } \\
\text { Method of concealment of } \\
\text { allocation not stated. } \\
\text { Patients received } \\
\text { concomitant therapy }\end{array}$ \\
\hline $\begin{array}{l}\text { Bagnenko et al 2011, Russia, } \\
\text { St Petersburg Research } \\
\text { Institute Emergency care }\end{array}$ & & & $\begin{array}{l}\text { IV Tranexamic acid } 750 \mathrm{mg}(10 \mathrm{mg} / \mathrm{kg}) \text { per } 200 \mathrm{ml} \text { of } \\
\text { nat. solution } 3 \text { times a day for } 1-3 \text { days and via gastric } \\
\text { tube } 750 \mathrm{mg} \text { of drug in } 50 \mathrm{ml} \text { of nat. solution } 3 \text { times } \\
\text { daily in the first day. This was given in addition to } \\
\text { conservative therapy }\end{array}$ & $\begin{array}{l}\text { Only conservative therapy administered. } \\
\text { Bolus IV Famotidine } 40 \mathrm{mg} 4 \text { times daily }\end{array}$ & $\begin{array}{l}\text { RCT. Methods of } \\
\text { randomization and } \\
\text { allocation concealment not } \\
\text { stated. Patients received } \\
\text { concomitant therapy. }\end{array}$ \\
\hline
\end{tabular}


FIGURE 4. Forest plot of randomized controlled trials of tranexamic acid vs placebo in preventing all-cause mortality in UGIB

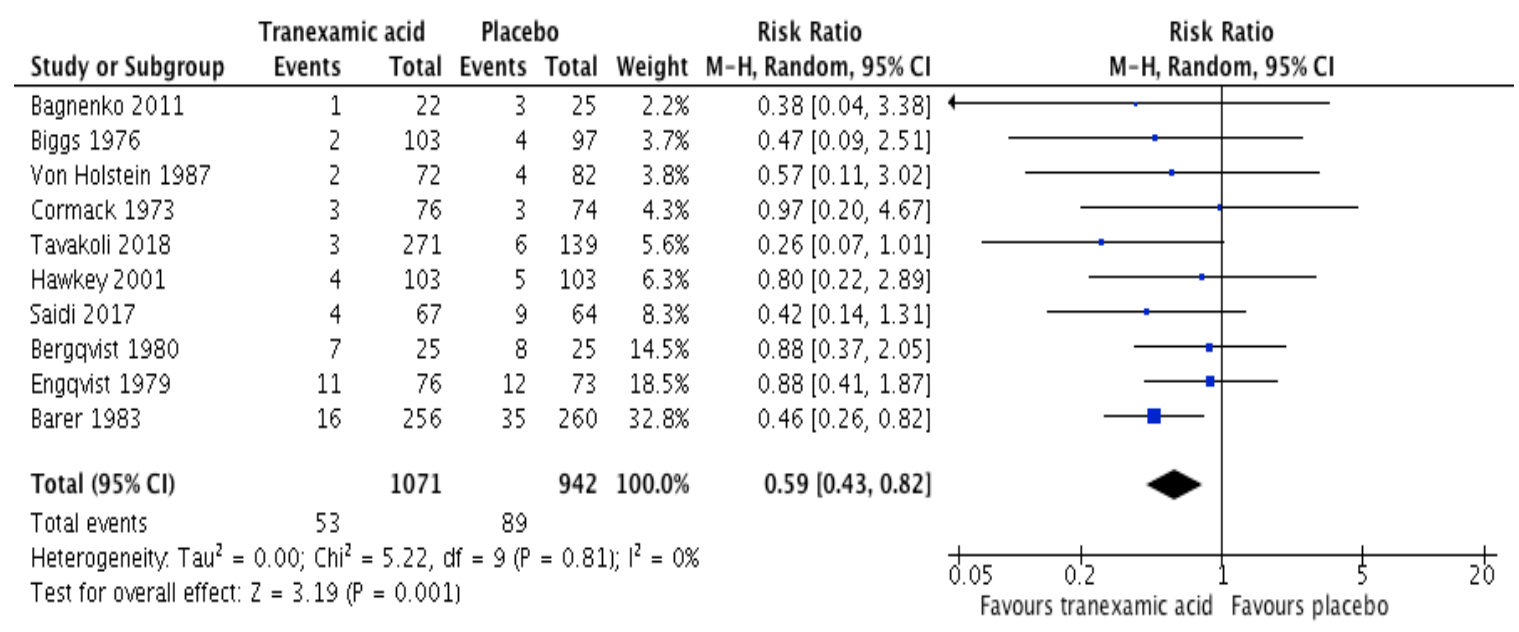

FIGURE 5. Forest plot of randomized controlled trials of tranexamic acid vs placebo in preventing all-cause mortality in UGIB (Fixed effects Model)

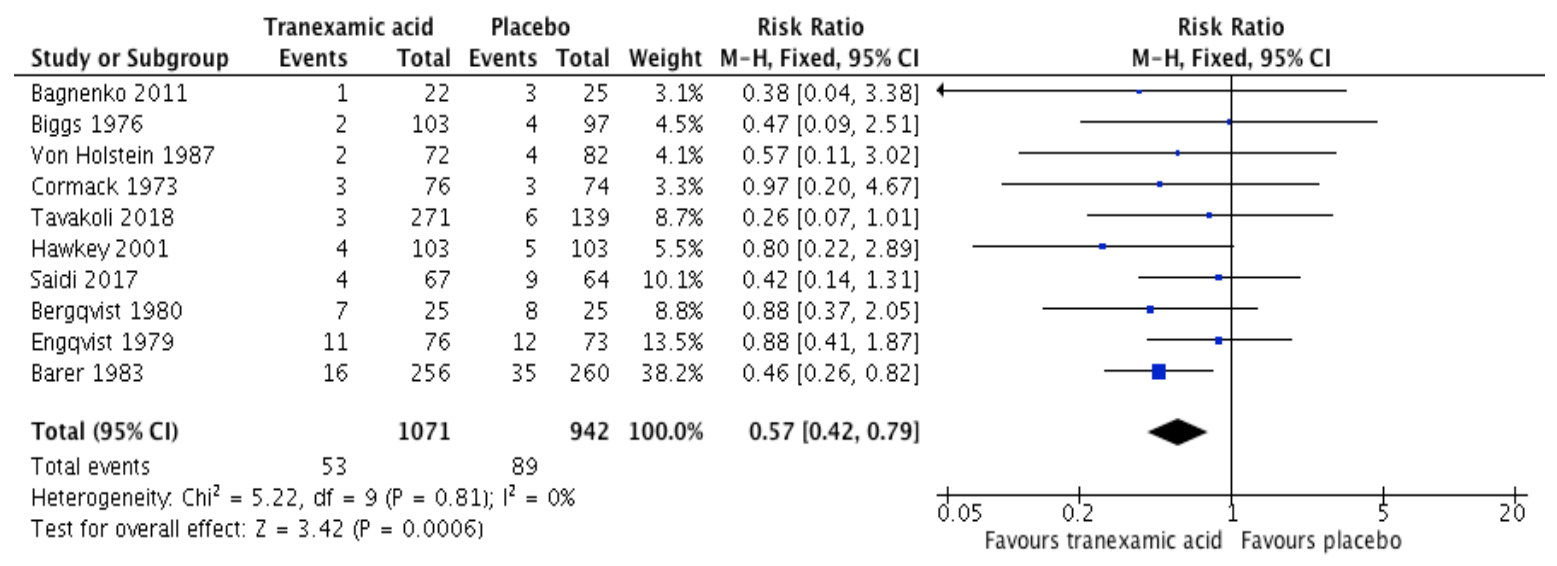

FIGURE 6. Forest plot of randomized controlled of tranexamic acid vs placebo in preventing rebleeding in UGIB

Tranexamic acid Placebo Risk Ratio

Risk Ratio

Study or Subgroup Events Total Events Total Weight M-H, Random, $95 \% \mathrm{Cl}$

$\mathrm{M}-\mathrm{H}$, Random, $95 \% \mathrm{Cl}$

\begin{tabular}{|c|c|c|c|c|c|c|c|c|c|}
\hline Bagnenko 2011 & 2 & 22 & 5 & 25 & $2.6 \%$ & $0.45[0.10,2.11]$ & - & & 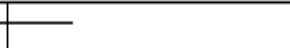 \\
\hline Saidi 2017 & 4 & 67 & 12 & 64 & $5.0 \%$ & $0.32[0.11,0.94]$ & & & \\
\hline Hawkey 2001 & 9 & 103 & 10 & 103 & $7.5 \%$ & $0.90[0.38,2.12]$ & & & \\
\hline Von Holstein 1987 & 10 & 69 & 19 & 72 & $10.8 \%$ & $0.55[0.28,1.10]$ & & & \\
\hline Tavakoli 2018 & 20 & 271 & 13 & 139 & $11.4 \%$ & $0.79[0.40,1.54]$ & & & \\
\hline Cormack 1973 & 15 & 76 & 20 & 74 & $13.9 \%$ & $0.73[0.41,1.31]$ & & & \\
\hline Engqvist 1979 & 23 & 76 & 29 & 73 & $20.6 \%$ & $0.76[0.49,1.19]$ & & & \\
\hline Barer 1983 & 58 & 256 & 51 & 260 & $28.2 \%$ & $1.16[0.83,1.61]$ & & & - \\
\hline Total $(95 \% \mathrm{Cl})$ & & 940 & & 810 & $100.0 \%$ & $0.79[0.61,1.02]$ & & & \\
\hline Total events & 141 & & 159 & & & & & & \\
\hline \multicolumn{6}{|c|}{$\begin{array}{l}\text { Heterogeneity. Tau }{ }^{2}=0.03 ;\left(\mathrm{Chi}^{2}=9.14, \mathrm{df}=7(\mathrm{P}=0.24) ;\left.\right|^{2}=23 \%\right. \\
\text { Test for overall effect: } Z=1.83(P=0.07)\end{array}$} & & $\begin{array}{cc}0.05 & 0.2 \\
\text { Favours transe }\end{array}$ & examic acid & $1 \frac{1}{5}$ \\
\hline
\end{tabular}


FIGURE 7. Forest plot of randomized controlled trials of tranexamic acid vs placebo in preventing the need for surgical interventions in UGIB

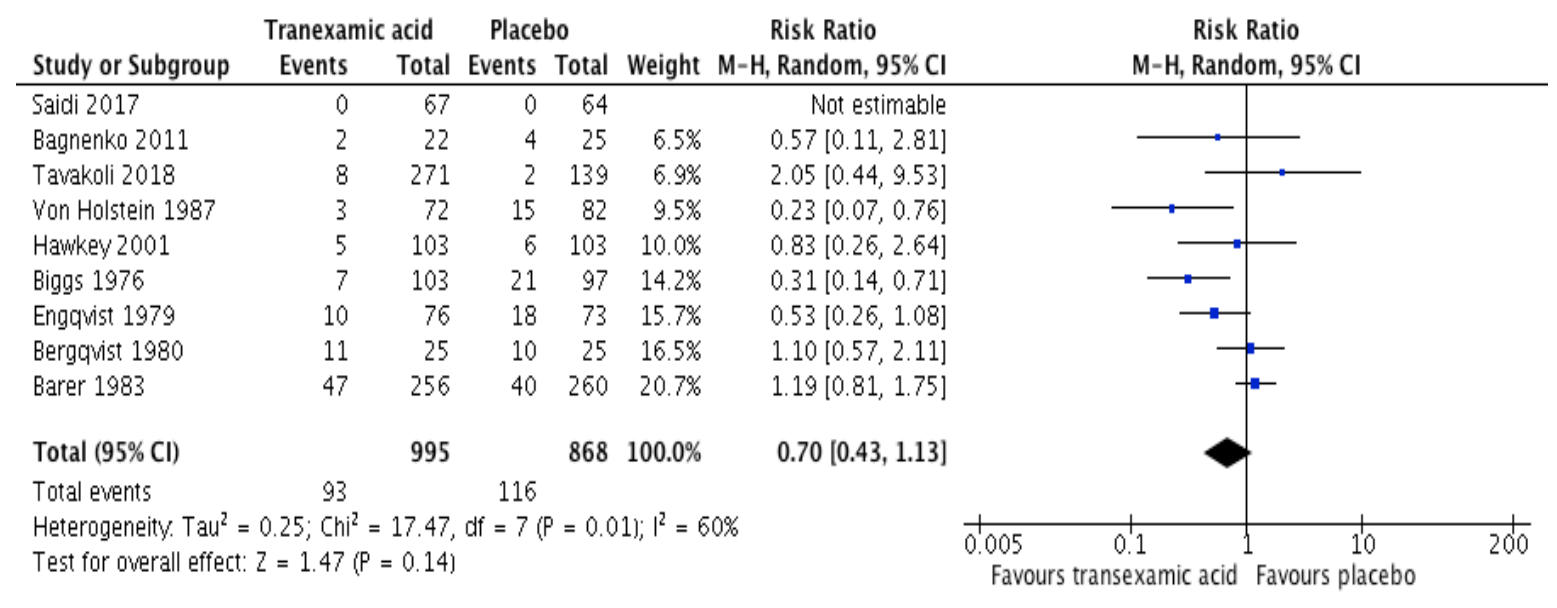

FIGURE 8. Forest plot of randomized controlled trials reporting the frequency of blood transfusions in tranexamic acid vs placebo groups in UGIB

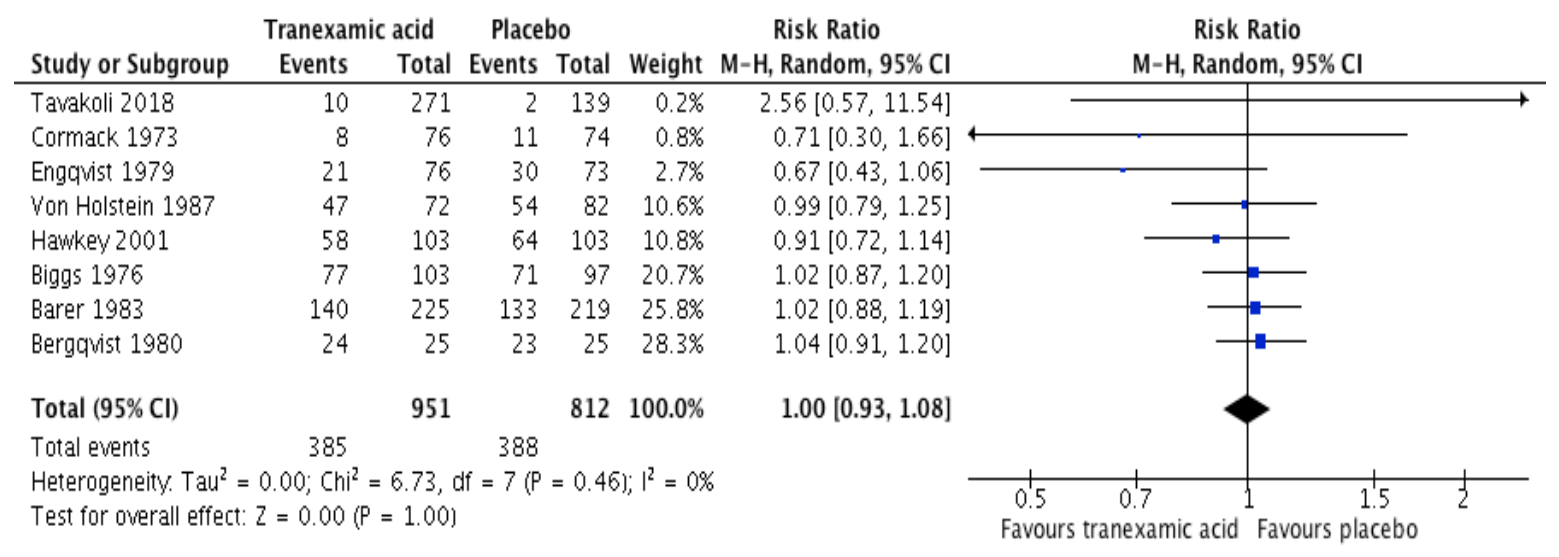

FIGURE 9. Forest plot of randomized controlled trials reporting the development of thromboembolic events in tranexamic acid vs placebo groups in UGIB

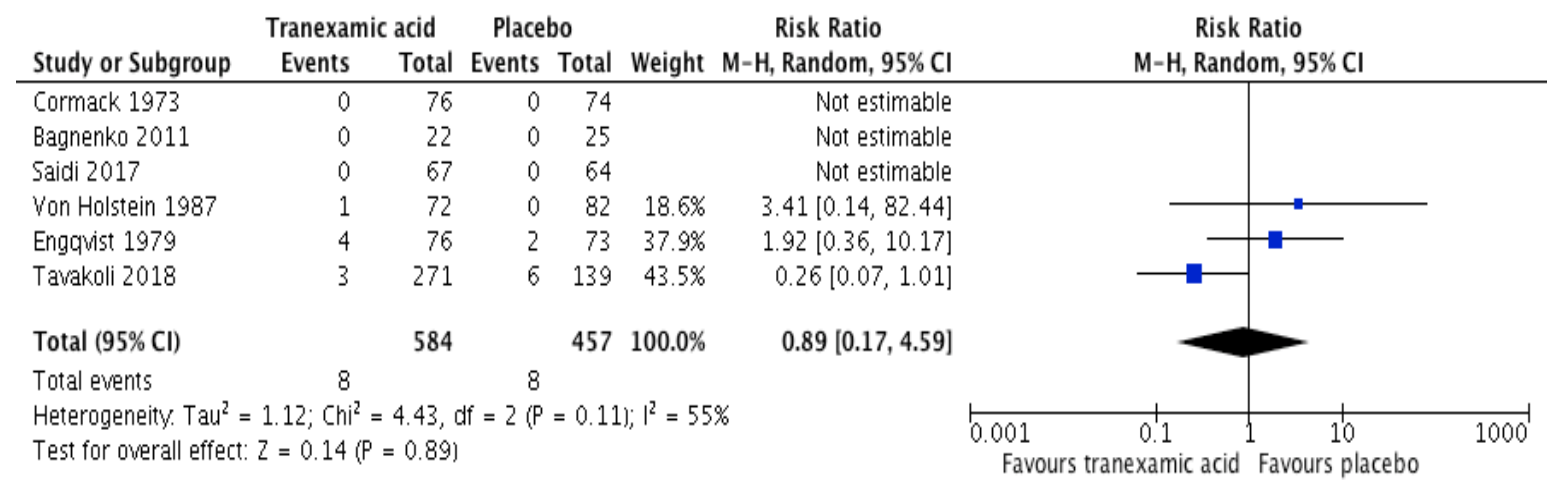


FIGURE 10. Forest plot or randomized controlled trials reporting the development of thrombophlebitis in tranexamic acid vs placebo groups in UGIB

\begin{tabular}{|c|c|c|c|c|c|c|c|c|}
\hline \multirow[b]{2}{*}{ Study or Subgroup } & \multicolumn{2}{|c|}{ Tranexamic acid } & \multicolumn{2}{|c|}{ Placebo } & \multicolumn{2}{|r|}{ Risk Ratio } & \multirow{2}{*}{$\begin{array}{c}\text { Risk Ratio } \\
\mathrm{M}-\mathrm{H}, \text { Random, } 95 \% \mathrm{Cl}\end{array}$} & \\
\hline & Events & Total & Events $T$ & Total & Weight & $\mathrm{M}-\mathrm{H}$, Random, $95 \% \mathrm{Cl}$ & & \\
\hline Von Holstein 1987 & 2 & 72 & 0 & 82 & $25.5 \%$ & $5.68[0.28,116.50]$ & + & \\
\hline Biggs 1976 & 3 & 103 & 2 & 97 & $74.5 \%$ & $1.41[0.24,8.27]$ & & \\
\hline Total $(95 \% \mathrm{Cl})$ & & 175 & & 179 & $100.0 \%$ & $2.02[0.44,9.26]$ & & \\
\hline Total events & 5 & & 2 & & & & & \\
\hline $\begin{array}{l}\text { Heterogeneity. Tau }{ }^{2} \\
\text { Test for overall effect }\end{array}$ & $\begin{array}{l}0.00 ; \mathrm{Chi}^{2} \\
\mathrm{Z}=0.90\langle\mathrm{P}\end{array}$ & $\begin{array}{l}0.62, \mathrm{~d} \\
=0.371\end{array}$ & df $=1(P=$ & $=0.43$ & $1 ;\left.\right|^{2}=0 \%$ & & $\begin{array}{cccc}0.002 & 0.1 & 1 & 10 \\
& \text { Favours tranexamic acid } & \text { Favours plac }\end{array}$ & 500 \\
\hline
\end{tabular}




\section{REFERENCES}

1. Abdelrahman M, Hornby S. Upper gastrointestinal haemorrhage. Surg J. 2017;35:649-57.

2. Suchartlikitwong S, Lapumnuaypol K, Rerknimitr R, Werawatganon D. Epidemiology of upper gastrointestinal bleeding and Helicobacter pylori infection: Review of 3,488 Thai patients. Asian Biomed. 2015;9:87-93.

3. Jafar W, Jafar A, Sharma A. Upper gastrointestinal haemorrhage: An update. Front Gastroenterol. 2016;7:32-40.

4. Chertoff J, Lowther G, Alnuaimat H, Ataya A. The use of tranexamic acid for upper gastrointestinal bleeding by medical and surgical Intensivists: A single center experience. Gastroenterol Res [Internet]. 2017;10:235-7.

5. Martí-Carvajal A, Solà I, Nicita G. Antifibrinolytic amino acids for upper gastrointestinal bleeding in people with acute or chronic liver disease. Cochrane Database Syst Rev [Internet]. 2015;6:N.PAG-N.PAG 1p. Available from:

http://search.ebscohost.com/login.aspx?direct=true\&AuthType=ip,shib\&db=jlh\&AN=105839 005\&site=ehost-live $\&$ scope $=$ site

6. Dunn CJ, Goa KL. Tranexamic acid: A review of its use in surgery and other indications. Drugs. 1999;57:1005-32.

7. Roberts I, Prieto-Merino D, Manno D. Mechanism of action of tranexamic acid in bleeding trauma patients: An exploratory analysis of data from the CRASH-2 trial. Crit Care. 2014;18.

8. Reed MR, Woolley LCT. Uses of tranexamic acid. Contin Educ Anaesthesia, Crit Care Pain. 2015;15:32-7.

9. Kit Ng WC, Jerath A, Wasowicz M. Tranexamic acid: A clinical review. Anestezjol Intens Ter. 2015;47:339-50.

10. Jiang $\mathrm{M}, \mathrm{Chen} \mathrm{P}, \mathrm{Gao} \mathrm{Q}$. Systematic Review and Net-Work Meta-Analysis of Upper Gastrointestinal Hemorrhage Interventions. Vol. 39, Cellular Physiology and Biochemistry. 2016. p. 2477-91.

11. Bennett C, Klingenberg SL, Langholz E, Gluud LL. Tranexamic acid for upper gastrointestinal bleeding. Cochrane Database of Systematic Reviews. 2014.

12. Saidi H, Shojaie S, Ghavami Y, Mirafzal A, Sisakht MT, Sotudehnia M. Role of intra-gastric tranexamic acid in management of acute upper gastrointestinal bleeding. lioab J. 2017;8(1):76-81.

13. Tavakoli N, Mokhtare M, Agah S, Azizi A, Masoodi M, Amiri H, et al. Comparison of the efficacy of intravenous tranexamic acid with and without topical administration versus placebo in urgent endoscopy rate for acute gastrointestinal bleeding: A double-blind randomized controlled trial. United Eur Gastroenterol J. 2018;6(1):46-54.

14. Rafeey M, Shoaran M, Ghergherechi R. Topical tranexamic acid as a novel treatment for bleeding peptic ulcer: A randomised controlled trial. African J Paediatr Surg. 2016;13:9-13.

15. Moher D, Liberati A, Tetzlaff J, Altman DG. Preferred reporting items for systematic reviews and meta-analyses: the PRISMA statement. J Clin Epidemiol. 2009;62(10):1006-12.

16. Higgins JP, Altman DG. Assessing Risk of Bias in Included Studies. In: Cochrane Handbook for Systematic Reviews of Interventions: Cochrane Book Series. 2008. p. 187-241.

17. Higgins J, Thompson S. Quantifying heterogeneity in a meta-analysis. Stat Med [Internet]. 
2002;21:1539-58. Available from: https://www.ncbi.nlm.nih.gov/pubmed/12111919

18. Higgins JPT. Cochrane Handbook for Systematic Reviews of Interventions -

Handbook510pdf_Ch08_RiskOfBias.pdf [Internet]. updated March 2011. 2011. Available

from:

http://www.cochrane.org/sites/default/files/uploads/handbook/Handbook510pdf_Ch08_Ris kOfBias.pdf

19. Bagnenko S, Verbitsky V. Antifibrinolytic therapy in the complex treatment of massive gastrointestinal bleeding. 2011. p. 42-6.

20. Cormack FCRR. JAJ. FGR. Tranexamic Acid in Upper Gastrointestinal HAemorrhage. 1973. p. 1207-8.

21. Biggs JC, Hugh TB, Dodds J. Tranexamic acid for upper gastrointestinal haemorrhagw: a double blind trial. Transfusion. 1976;17:729-34.

22. Bergqvist $D$, Dahlgren $S$, Hessman $Y$. Local inhibition of the fibrinolytic system in patients with massive upper gastrointestinal hemorrhage. Ups J Med Sci. 1980;85(2):173-8.

23. Barer D, Ogilvie A, Henry D, Dronfield M, Coggon D, French S, et al. Cimetidine and Tranexamic Acid in the Treatment of Acute Upper-Gastrointestinal-Tract Bleeding. N Engl J Med. 2010;308:1571-5.

24. Staël Von Holstein CCS, Eriksson SBS, Kallen R. Tranexamic acid in gastric and duodenal bleeding. Scand J Gastroenterol. 1987;22:71-4.

25. Engqvist A, Broström O, Feilitzen F V., Halldin M, Nyström B, Öst Å, et al. Tranexamic acid in massive haemorrhage from the upper gastrointestinal tract: A double-blind study. Vol. 14, Scandinavian Journal of Gastroenterology. 1979. p. 839-44.

26. Hawkey G, Cole A, Mclntyre A, Long R, Hawkey C. Drug treatments in upper gastrointestinal bleeding: value of endoscopic findings as surrogate end points. Gut [Internet]. 2001;49:3729. Available from: http://www.epistemonikos.org/documents/df1e70ddba9abbd9cba8903165f4220ff285d119

27. Laine L, Jensen DM. Management of patients with ulcer bleeding. Am J Gastroenterol. 2012;107:345-60.

28. NICE Guideline. Acute upper gastrointestinal bleeding overview. 2019;1-12.

29. Roberts I, Coats T, Edwards P, Gilmore I, Jairath V, Ker K, et al. HALT-IT - tranexamic acid for the treatment of gastrointestinal bleeding: Study protocol for a randomised controlled trial. Trials. 2014;15. 